\title{
Keterbukaan Komunikasi dalam Menciptakan Iklim Komunikasi yang Kondusif di Perpustakaan
}

\author{
(Studi Kasus Tentang Keterbukaan Komunikasi dalam Menciptakan Iklim \\ Komunikasi yang Kondusif di Kapusipda Kabupaten Buleleng, Singaraja-Bali)
}

\author{
Putu Suparna, Tine Silvana R., dan Yunus Winoto \\ Perpustakaan Undiknas Bali \\ Program Studi Ilmu Informasi dan Perpustakaan
}

\begin{abstract}
Abstrak - Penelitian ini bertujuan untuk: 1) mengetahui keterbukaan komunikasi dalam menciptakan iklim komunikasi yang kondusif di Kapusipda Kabupaten Buleleng dari aspek komunikasi atasan; 2) mengetahui keterbukaan komunikasi dalam menciptakan iklim komunikasi yang kondusif di Kapusipda Kabupaten Buleleng dari aspek komunikasi bawahan ; 3) mengetahui implikasi keterbukaan komunikasi dalam menciptakan iklim komunikasi yang kondusif di Kapusipda Kabupaten Buleleng. Metode penelitian menggunakan metode kualitatif pendekatan studi kasus. Informan kunci adalah pengelola Kapusipda Kabupaten Buleleng, sebanyak sepuluh narasumber. Hasil penelitian menunjukkan sebagai berikut: 1) berdasarkan aspek komunikasi atasan belum sepenuhnya dilaksanakan karena masih terdapat beberapa atasan yang tidak pernah mengkomunikasikan pada bawahan, misalnya hasil rapat. Seyogyanya atasan yakni kepala seksi harus menyediakan informasi atau dapat menjembatani antara bawahan dengan pimpinan yang lebih tinggi lagi kedudukannya dalam organisasi tersebut; 2) berdasarkan aspek komunikasi bawahan terlihat sudah berjalan efektif yang berarti adanya hubungan komunikasi antara bawahan dan atasan yang efektif sesuai kondisi lingkungan dan seimbang. Adanya kesediaan atasan mendengarkan keluhan atau kesulitan pekerjaan dan menerima saran atau gagasan yang disampaikan bawahannya dengan cara membuka pintu lebar-lebar bagi bawahan; 3) implikasi keterbukaan komunikasi dalam menciptakan iklim komunikasi yang kondusif di Kapusipda Kabupaten Buleleng terlihat adanya kepercayaan, kedekatan, dukungan, dan bersedia mendengarkan masalah, serta bersedia menerima kelebihan dan kekurangan.
\end{abstract}

Kata Kunci : keterbukaan komunikasi, iklim komunikasi.

Abstract - This study aimed to find out about 1) communication transparency in creating conducive communication climate in Kapusipda Kabupaten Buleleng from the aspects of managers; 2) communication transparency in creating conducive communication climate in Kapusipda Kabupaten Buleleng from the aspects of subordinates; 3) implications of communication transparency in creating conducive communication climate. The study used the qualitative method and study case approach. The key informants are ten managers of Kapusipda Kabupaten Buleleng. Research results showed as follows: 1) based on manager communication aspects, it has not been fulfilled yet since it is found that there are still some managers who do not communicate to subordinates, such as the results of meetings. Actually, superiors such as the head of a section should prepare information or act as a bridge between subordinates and managers in the organization; 2) based on subordinate communication aspects, it is working effectively meaning there is communication relation between subordinates and superiors appropriate to the environmental conditions and balanced; 3) implications of communication transparency in creating conducive communication climate in Kapusipda Kabupaten Buleleng show there is trust, closeness, support, and willingness to listen to problems and willingness to accept differences.

Keywords: communication transparency, communication climate

\section{PENDAHULUAN}

Keterbukaan komunikasi atasan dan bawahan atau antara sesama rekan kerja sering memberikan dorongan semangat kerjasama pada masing-masing individu atau anggota organisasi. Atasan memberikan dorongan, kepercayaan dan penghargaan kepada bawahannya akan dapat meningkatkan semangat kerjasama pada bawahan dalam bekerja. Demikian pula komunikasi antara sesama rekan kerja yang efektif dan efisien dapat meningkatkan kerjasama dalam bekerja. Terkadang ada hal-hal yang sulit disampaikan dalam suatu komunikasi yang menyebabkan adanya kesalahpahaman, kurangnya keterbukaan, dan hal-hal penghambat lainnya dalam sebuah hubungan antar manusia.

Adanya sikap terbuka (open-mindedness) merupakan salah satu substansi dalam organisasi yang harus dilaksanakan. Dalam suatu organisasi, pimpinan seyogyanya dapat memfasilitasi kondisi 
munculnya keterbukaan. Suasana keterbukaan terwujud bila pimpinan maupun karyawan dapat berinteraksi secara jujur. Maka penting terjadinya komunikasi secara tatap muka untuk mengubah sikap, pendapat dan perilaku seseorang. Agar komunikasi berjalan lancar, seorang pemimpin perlu bersikap tanggap terhadap apa yang disampaikan oleh karyawan karena syarat keterbukaan, seorang pemimpin bersedia dalam menerima masukan dan kritikan yang disampaikan karyawannya.

Namun, lain halnya individu atau anggota organisasi yang mempunyai peran di Kantor Perpustakaan dan Arsip Daerah Kabupaten Buleleng, dirasakan adanya ketidaksesuaian keinginan dan tujuan. Adanya konflik yang terjadi, Kepala Kapusipdaselaku pimpinan yang membawahi unit-unit di lingkungan Kantor Perpustakaan dan Arsip Daerah Kabupaten Buleleng, seyogyanya melihat konflik yang terjadi dan menyelesaikannya secara kekeluargaan. Kurangnya sikap terbuka dan kurang perhatian pimpinan terhadap bawahan, antara unit satu dengan unit yang lain tidak bisa menunjukkan kebersamaan, alokasi anggaran dan pengelolaan dana kegiatan masih belum sepenuhnya terbuka sehingga menimbulkan prasangka-prasangka/ kecurigaan yang berujung pada suatu konflik di lingkungan internal.

Sebagai salah satu bagian dari satuan perangkat kerja daerah (SKPD), Kapusipda Kabupaten Buleleng, yang berorientasi pada pusat layanan informasi dan sumber memori di daerah. dituntut untuk dapat meningkatkan kinerjanya sesuai visi dan misi yang ditetapkan selain memberikan layanan kepada seluruh lapisan masyarakat.

Komunikasi antara atasan dan bawahan maupun antar karyawan yang efektif dapat membantu menentukan iklim dan semangat kerja sehingga diharapkan mampu memberikan pencerahan dan kemudahan dalam mengelola sebuah organisasi, yakni keterbukaan komunikasi, pemahaman yang sama, saling berbagi dan lain sebagainya. Sedangkan komunikasi yang kurang efektif adanya kepentingan-kepentingan, komunikasi yang terpendam, prasangka atau curiga yang menyebabkan pertentangan. Namun demikian selain beberapa faktor yang telah dijelaskan mengenai komunikasi dalam organisasi ada hal lain yang dapat memberikan warna bagi sebuah organisasi yakni budaya organisasi.
Budaya organisasi merupakan sekumpulan nilai dan kebiasaan yang diyakini, diciptakan, dibakukan secara formal maupun informal oleh anggota organisasi, yang berfungsi sebagai pedoman dalam bertingkah laku dan pengelolaan organisasi untuk mencapai apa yang diinginkan sebagai tujuan organisasi.

Menurut pandangan Joseph A. DeVito (2011:259), bahwa salah satu karakteristik komunikasi efektif adalah keterbukaan, kualitas keterbukaan komunikasi setidaknya menunjukkan tiga aspek, yaitu: 1) saling terbuka dalam berkomunikasi sehingga terjadi pertukaran informasi, yakni komunikator bersedia menyampaikan secara lengkap informasi yang seharusnya disampaikan kepada komunikan. 2) berkomunikasi untuk bereaksi secara jujur, yakni komunikator mengungkapkan secara spontan reaksinya (tidak dibuat-buat) kepada komunikan. 3) komunikator bertanggung jawab terhadap apa yang diungkapkan. Dengan keterbukaan komunikasi dan proses menciptakan suatu organisasi yang kondusif, sangat berpengaruh terhadap kinerja individu atau anggota organisasi maupun efektivitas organisasi itu sendiri. Organisasi berjalan efektif apabila iklim organisasi tersebut berlangsung dengan kondusif. Suasana kondusif merupakan sebuah keadaan "aman terkendali" yang bisa dikatakan selaras, nyaman, sesuai kondisi yang tercipta dengan baik.

Komunikasi atasan dan bawahan maupun sesama rekan kerja berperan penting dalam memberikan motivasi dan produktivitas kerja seluruh individu atau anggota organisasi. Tujuan keterbukaan komunikasi untuk terjalinnya keharmonisan komunikasi atasan dan komunikasi bawahan, sehingga tercipta iklim komunikasi yang kondusif. Persoalan-persolan terjadi di Kantor Perpustakaan dan Arsip Daerah Kabupaten Buleleng, seperti; kurangnya sikap terbuka antara atasaan dan bawahan tentang keluhan dan gagasan atau pendapat, kurangnya penghargaan bagi karyawan yang masa kerjanya sudah cukup lama, kurang adanya kesepahaman dan keselarasan antar anggota atau kurang perhatian atasan yang berujung adanya karyawan/bawahan yang masuk dan pulang kerja sesuai kehendaknya sendiri. Hal ini yang melatarbelakangi ketertarikan peneliti untuk menelaah lebih dalam tentang keterbukaan komunikasi dalam menciptakan iklim komunikasi yang kondusif di Kantor Perpustakaan dan Arsip Daerah Kabupaten Buleleng. 
Penelitian ini menggunakan pendekatan studi kasus dengan judul "Keterbukaan Komunikasi dalam Menciptakan Iklim Komunikasi yang Kondusif di Perpustakaan, Studi Kasus Mengenai Keterbukaan Komunikasi dalam Menciptakan Iklim Komunikasi yang Kondusif di Kapusipda Kabupaten Buleleng, Singaraja-Bali”.

\section{Tujuan Penelitian}

Penelitian ini bertujuan:

1) Mengetahui keterbukaan komunikasi dalam menciptakan iklim komunikasi yang kondusif di Kapusipda Kabupaten Buleleng dari aspek komunikasi atasan.

2) Mengetahui keterbukaan komunikasi dalam menciptakan iklim komunikasi yang kondusif di Kapusipda Kabupaten Buleleng dari aspek komunikasi bawahan.

3) Mengetahui implikasi keterbukaan komunikasi dalam menciptakan iklim komunikasi yang kondusif di Kapusipda Kabupaten Buleleng.

\section{Fokus Penelitian}

Adapun fokus penelitian dalam penelitian ini, yakni dengan merumuskan "Bagaimana Keterbukaan Komunikasi dalam Menciptakan Iklim Komunikasi yang Kondusif di Kantor Perpustakaan dan Arsip Daerah Kabupaten Buleleng".

\section{Pertanyaan Penelitian}

Untuk lebih memperjelas fokus penelitian, akan diuraikan secara terperinci pertanyaan penelitian sebagai berikut:

1) Bagaimana keterbukaan komunikasi dalam menciptakan iklim komunikasi yang kondusif di Kapusipda Kabupaten Buleleng dari aspek komunikasi atasan?

2) Bagaimana keterbukaan komunikasi dalam menciptakan iklim komunikasi yang kondusif di Kapusipda Kabupaten Buleleng dari aspek komunikasi bawahan?

3) Implikasi keterbukaan komunikasi dalam menciptakan iklim komunikasi yang kondusif di Kapusipda Kabupaten Buleleng?

\section{METODOLOGI}

\section{Paradigma Penelitian}

Penelitian menggunakan paradigma konstruktivisme dengan metode kualitatif, yaitu untuk menginterpretasikan dan menjelaskan suatu fenomena secara holistik dengan menggunakan kata-kata, tanpa harus bergantung pada sebuah angka.

\section{Jenis Penelitian}

Jenis penelitian yang digunakan dalam penelitian ini adalah metode kualitatif, dengan pendekatan studi kasus.

Tujuannya adalah memberi pandangan yang lengkap dan mendalam mengenai subjek yang diteliti.

1) Jenis Kasus

Jenis kasus tunggal (single case study), yaitu suatu penelitian yang arah sasarannya terpusat pada satu karakteristik saja.

2) Sifat Kasus

Penelitian ini menggunakan sifat kasus mendalam (intrinsic case study). Sifat kasus intrinsik dalam penelitian kualitatif, yaitu untuk lebih memahami sebuah kasus tertentu.

3) Jenis Studi Kasus

Dalam penelitian ini menggunakan jenis studi kasus eksploratif yang merupakan sebuah kasus dipakai untuk memperoleh data/ informasi awal bagi penelitian sosial yang akan dilakukan.

Pertimbangan penelitian kualitatif dengan pendekatan studi kasus yakni :

1) Kasus yang diteliti memiliki keunikan dan menarik untuk dikaji, serta peneliti memiliki kesempatan untuk melakukan penelitian di Kapusipda Kabupaten Buleleng, tentang keterbukaan komunikasi dan iklim komunikasi yang kondusif.

2) Mempelajari subyek penelitian sehingga informasi yang yang berkaitan dengan subyek penelitian yang diteliti secara menyeluruh melalui pengamatan, wawancara mendalam dan studi pustaka.

3) Mengungkapkan segala yang terjadi dalam penelitian sehingga dapat dijadikan acuan maupun referensi metode pembelajaran baru.

\section{Sumber dan Jenis Data}

Subyek informan terkait dengan keterbukaan komunikasi dalam menciptakan iklim komunikasi yang kondusif di Kapusipda Kabupaten Buleleng yaitu Kepala Kapusipda, Kasubbag Tata Usaha dan Staf serta pihak lain yang berhubungan dengan keterbukaan komunikasi di perpustakaan. Sedangkan objek penelitiannya yaitu keterbukaan komunikasi dan iklim komunikasi. Berdasarkan sumber data, 
yaitu data primer berupa kata-kata dan perilaku individu atau anggota organisasi. Sedangkan data sekunder berupa dokumen dan data statistik.

Penentuan informan kunci yang peneliti lakukan dalam penentuan sampel atau pemilihan informan adalah dengan menggunakan metodePurposive Sampling. Tujuannya untuk mendapatkan informasi yang maksimal tentang keterbukaan komunikasi dalam menciptakan iklim komunikasi kondusif di Kapusipda Kabupaten Buleleng. Informan kunci dalam penelitian ini sebanyak 10 (sepuluh) informan, yakni: Pakar/ahli Bidang Ilmu Komunikasi Universitas Padjadjaran Bandung; Kepala Kapusipda Kabupaten Buleleng; Kasubag Tata Usaha; Kasi Pelayanan dan Referensi; Kasi Akuisisi dan Pengolahan; Kasi Pengelola Arsip; Staf Tata Usaha; Staf Pelayanan dan Referensi; Staf Akuisisi dan Pengolahan; dan Staf Pengelola Arsip.

\section{1) Proses Pendekatan (Gaining Access dan Making Rapport) \\ Dalam penelitian ini, proses pendekatan yang disebut "gaining access and making rapport", sebagai berikut :}

(1) Gaining Access

Adapun tahapan peneliti dalam memperoleh akses tentang keterbukan komunikasi dalam menciptakan iklim komunikasi yang kondusif dari individu/anggota organisasi yang terlibat dalam suatu peristiwa di Kapusipda Kabupaten Buleleng, melalui pendekatan struktural dan bersifat formal.

(2) Making Rapport

Sedangkan dalam memperoleh kedekatan, peneliti melakukan langkahlangkah kedekatan dengan tiap individu yang menjadi key informan melalui pendekatan personal dan bersifat informal.

2) Lokasi dan Waktu Penelitian

Lokasi penelitian dilangsungkan di Kantor Perpustakaan dan Arsip Daerah Kabupaten Buleleng, yang terletak di Jalan Werkudara No. 1 Singaraja-Bali. Peneliti melakukan proses pra penelitian terlebih dahulu melalui observasi dan wawancara tidak resmi.

Proses penelitian dilakukan dari bulan Pebruari 2013 sampai dengan Januari 2014. Diperkirakan memakan waktu dua belas bulan.
Penelitian ini dilakukan mulai dari proses persiapan, penelitian di lapangan, dan penyusunan.

\section{Teknik Pengumpulan Data}

Teknik pengumpulan data yang peneliti gunakan dalam penelitian ini, sebagai berikut :

1) Wawancara Mendalam (In depth interview)

2) Observasi

3) Studi Pustaka/Dokumentasi

\section{Teknik Analisis Data}

Teknik analisis yang digunakan dalam penelitian ini adalah analisis kualitatif mengikuti konsep yang dikembangkan Miles and Huberman (1992), yakni analisis data dengan komponen, yaitu data reduction, data display, dan conclusion drawing/verification(Sugiyono, 2012: 246).

Selanjutnya, langkah-langkah analisis data tersebut secara lebih jelas dapat diuraikan sebagai berikut.

1) Pengumpulan Data (data collection) merupakan kegiatan untuk memperoleh informasi yang berupa kalimat-kalimat yang dikumpulkan melalui kegiatan observasi, wawancara, dan dokumen.

2) Reduksi Data (data reduction) merupakan proses merangkum, memilah hal-hal yang pokok, memfokuskan pada hal-hal penting, dan mencari tema serta polanya sehingga dapat memberikan gambaran yang lebih jelas.

3) Penyajian Data (data display) yaitu mengorganisasi data dan menyusun pola hubungan sehingga data lebih mudah dipahami.

4) Penarikan Kesimpulan/Verifikasi (conclusion drawing/verification) yaitu menarik kesimpulan dari verifikasi atas pola keteraturan dan penyimpangan yang ada dalam fenomena yang timbul pada keterbukaan komunikasi dalam menciptakan iklim komunikasi yang kondusif di Kantor Perpustakaan dan Arsip Daerah Kabupaten Buleleng.

\section{Teknik Pemeriksaan Keabsahan Data}

Pemeriksaan keabsahan data dalam penelitian ini dilakukan dengan menggunakan teknik triangulasi. Teknik triangulasi yang digunakan dalam penelitian ini adalah triangulasi sumber. Triangulasi sumber dilakukan dengan cara mengecek data yang telah diperoleh melalui beberapa sumber. Obyek yang diteliti dalam 
penelitian ini adalah mengenai keterbukaan komunikasi dalam menciptakan iklim komunikasi yang kondusif.

\section{HASIL PENELITIAN}

Hasil penelitian ini menjelaskan mengenai gambaran umum Kantor Perpustakaan dan Arsip Daerah Kabupaten Buleleng mulai dari sejarah singkat, struktur organisasi, bahkan sarana dan prasarananya. Selain itu dibahas profil informan dalam penelitian ini sebagai informasi tambahan dan latar belakang penunjukkan informan tersebut. Selanjutnya dibahas mengenai konsep keterbukaan komunikasi dalam menciptakan iklim komunikasi yang kondusif di lembaga ini. Peneliti bahas satu persatu aspek yang ada dalam keterbukaan komunikasi dan iklim komunikasi diantaranya adalah aspek komunikasi, aspek komunikasi organisasi dan aspek iklim komunikasi.

\section{Proses Keterbukaan Komunikasi}

Untuk mengetahui proses keterbukaan komunikasi yang terjalin di Kantor Perpustakaan dan Arsip Daerah Kabupaten Buleleng, peneliti melakukan observasi dan wawancara terhadap peristiwa komunikasi yang terjalin pada organisasi tersebut. Komunikasi dalam organisasi merupakan suatu kompetensi awal bagi para anggota suatu organisasi informasi dalam hal ini pada bidang perpustakaan dan arsip dalam melaksanakan tugas pokok dan fungsinya di tempat ia bekerja dalam mewujudkan tujuan perpustakaan dan arsip. Dalam mengelola suatu organisasi dengan komunikasi yang baik akan memepermudah menjalankan tugas atau program kerja suatu organiasi. Dengan kata lain kemampuan berkomunikasi secara naluriah dimiliki setiap individu dan merupakan aset yang sangat berharga bagi individu tersebut sebagai modal dalam melakukan aktivitas organisasi.

Proses komunikasi yang terjalin di Kantor Perpustakaan dan Arsip Daerah Kabupaten Buleleng berjalan cukup baik, komunikasi terbuka apa adanya dimana komunikasi yang dilakukan mengalir begitu saja antara atasan dan bawahan ataupun sesama rekan kerja. Hanya saja tidak semua para anggota organisasi dapat memanfaatkan waktu dan peluang untuk saling berkomunikasi, berbagi dan lain sebagainya dikarenakan kesibukan rutinitas para karyawan.

\section{PEMBAHASAN}

Analisis dan interpretasi data yang disajikan adalah hasil observasi dan wawancara peneliti pada Kantor Perpustakaan dan Arsip Daerah Kabupaten Buleleng, yaitu dengan menggambarkan dan mengkaji tentang keterbukaan komunikasi yang terjalin dalam menciptakan iklim komunikasi yang kondusif di Kantor Perpustakaan dan Arsip Daerah Kabupaten Buleleng. Diawali dengan konsep-konsep komunikasi dalam organisasi, keterbukaan komunikasi dan iklim komunikasi yang telah dijelaskan pada kajian literatur sebagai acuan dalam mengumpulkan data lapangan yang nantinya akan di analisis dan diinterpretasikan yang dituangkan dalam pembahasan ini.

\section{Keterbukaan Komunikasi dalam Menciptakan Iklim Komunikasi yang Kondusif dari Aspek Komunikasi Atasan}

Komunikasi atasan merupakan informasi yang berlangsung ketika orang-orang yang berada pada tataran manajemen atau atasan mengirimkan pesan kepada bawahannya. Kebanyakan informasi dari atasan ke bawahan digunakan untuk menyampaikan pesan yang berhubungan dengan pemberian atau penyampaian instruksi kerja, penjelasan tentang pelaksanaan tugas, penyampaian informasi mengenai peraturan dan pemberian motivasi. Jenis informasi ini di rancang agar para bawahan memahami bagaimana pekerjaan yang berkaitan dengan tugas dalam organisasi, serta mengapa mereka melaksanakan tugas, untuk kemudian dapat dihayati bagaimana pekerjaan mereka membantu upaya organisasi mencapai sasaran.

Keterbukaan komunikasi dalam menciptakan iklim komunikasi yang kondusif di Kantor Perpustakaan dan Arsip Daerah (Kapusipda) Kabupaten Buleleng berdasarkan aspek komunikasi dari atasan pada bawahan terlihat dari bagaimana menyampaikan pesan berhubungan dengan penugasan kerja atau instruksi kerja, penjelasan tentang pelaksanaan tugas, dan informasi mengenai peraturanperaturan.

Proses keterbukaan komunikasi dari atasan kepada bawahan di Kapusipda Kabupaten Buleleng yang dilakukan secara formal. Komunikasi atasan yang terjadi berdasarkan struktural melalui kasubag tata usaha, kasi dan 
koordinator jabatan fungsional yang kemudian disampaikan kepada para bawahannya. Biasanya penyampaian informasi seperti pemberian atau penyampaian instruksi kerja melalui disposisi, dan disiplin kerja yang disampaikan dalam apel pagi setiap hari senin. Kemudian keterbukaan komunikasi secara informal komunikasi atasan kepada bawahan lebih bersifat kekeluargaan.

Kepala Kantor Perpustakaan dan Arsip Daerah (Kapusipda) Kabupaten Buleleng merupakan pejabat baru yang lebih kurang setahun memimpin dan mengelola Kapusipda Kabupaten Buleleng, segala sesuatunya diganti termasuk peraturan-peraturan yang lama. Karena ada peraturan-peraturan yang berlaku dilingkungan Kapusipda Kabupaten Buleleng tidak ada dibuat selain mengacu pada peraturan daerah (Perda) yang sudah ditetapkan, maka para staf yang sudah bekerja sejak lama Kapusipda Kabupaten Buleleng mengandalkan kemampuan komunikasinya untuk menafsirkan informasi dalam lingkungan barunya, yaitu dengan cara bertanya pada rekan sekerja dan sebagainya.

Keterbukaan komunikasi dalam menciptakan iklim komunikasi yang kondusif berdasarkan aspek komunikasi dari atasan pada bawahan dapat disimpulkan bahwa belum sepenuhnya dilaksanakan karena masih terdapat beberapa atasan yang tidak pernah mengkomunikasikan pada bawahan, misalnya hasil rapat tidak pernah informasinya sampai pada bawahan. Seharusnya bawahan juga harus mengetahui instruksi-instruksi terbaru dari hasil rapat dan hasil keputusan bersama pada saat rapat tersebut. Seyogyanya para atasan di sini yakni kepala seksi harus menyediakan informasi atau dapat menjembatani antara bawahan dengan pimpinan yang lebih tinggi lagi kedudukannya dalam organisasi tersebut.

\section{Keterbukaan Komunikasi dalam Menciptakan Iklim Komunikasi yang Kondusif dari Aspek Komunikasi Bawahan}

Komunikasi bawahan atau komunikasi dari bawahan kepada atasan merupakan komunikasi yang berada dalam jenjang hirarki yang lebih rendah dalam organisasi. Komunikasi yang efektif memerlukan keterbukaan yang sama, baik komunikasi atasan dirasakan sama dengan keterbukaan pada komunikasi bawahan. Komunikasi dari bawahan kepada atasan digunakan untuk menyampaikan informasi tentang pekerjaan yang telah dilaksanakan, tentang persoalan-persoalan pekerjaan atau tugas yang tidak dapat diselesaikan, saran-saran perbaikan, keluhan tentang diri sendiri maupun tentang pekerjaan. Beberapa fasilitas yang dapat dipakai untuk melakukan komunikasi dari bawahan kepada atasan diantaranya melalui pertemuan kelompok, kotak saran. Komunikasi antara bawahan dan atasan sangat tergantung pada situasi atasan, sedangkan menerka situasi seseorang sangat sulit, apakah atasan pada saat itu lagi baik-baik saja atau apakah atasan saat itu lagi punya masalah, sehingga para bawahan merasa takut, apalagi para bawahan yang biasa saja dan hubungan mereka tidak begitu dekat dan bahkan bukan kerabat atau sanak saudara.

Keterbukaan komunikasi dalam menciptakan iklim komunikasi yang kondusif berdasarkan aspek komunikasi bawahan atau komunikasi dari bawahan kepada atasan dapat disimpulkan bahwa komunikasi dari bawahan kepada atasan sudah berjalan efektif yang artinya hubungan komunikasi bawahan dan atasan yang sesuai dengan lingkungan yang ada dan seimbang. Adanya kesediaan atasan dalam mendengarkan keluhan atau kesulitan dalam pekerjaan dan menerima saran atau gagasan yang disampaikan bawahannya dengan cara membuka pintu lebarlebar bagi bawahan untuk berkomunikasi mengenai pekerjaan kepada atasan.

\section{Implikasi Keterbukaan Komunikasi Dalam Menciptakan Iklim Komunikasi yang Kondusif}

Berdasarkan temuan dari hasil wawancara mengenai implikasi keterbukaan komunikasi dalam menciptakan iklim komunikasi yang kondusif di Kantor Perpustakaan dan Arsip Daerah Kabupaten Buleleng yaitu :

1) adanya kepercayaan,

2) kedekatan,

3) dukungan,

4) bersedia mendengarkan masalah,

5) bersedia menerima kelebihan dan kekurangan.

Menurut Joseph A. Devito, dalam buku Komunikasi Antar Manusia mengatakan bahwa salah satu ciri atau karakteristik komunikasi antarpribadi yang efektif adalah keterbukaan. Sedangkan faktor-faktor yang mempengaruhi keterbukaan komunikasi menurut Rakhmat (2008:129), yaitu:

1) percaya (trust),

2) sikap suportif dan 
3) sikap terbuka.

\section{SIMPULAN}

Penelitian mengenai keterbukaan komunikasi dalam menciptakan iklim komunikasi yang kondusif di lingkungan Kapusipda Kabupaten Buleleng terlihat pada pola keterbukaan komunikasi dan faktor yang mempengaruhi keterbukaan komunikasi serta nilai-nilai pembentuk iklim komunikasi.

1) Keterbukaan komunikasi dalam menciptakan iklim komunikasi yang kondusif berdasarkan aspek komunikasi atasan dapat disimpulkan bahwa belum sepenuhnya dilaksanakan karena masih terdapat beberapa atasan (kepala seksi) yang tidak pernah mengkomunikasikan pada bawahan, misalnya hasil rapat tidak pernah informasinya sampai pada bawahan. Seharusnya bawahan mengetahui instruksiinstruksi terbaru dari hasil rapat dan hasil keputusan bersama pada saat rapat tersebut. Seyogyanya para atasan di sini yakni kepala seksi harus menyediakan informasi atau dapat menjembatani antara bawahan dengan pimpinan yang lebih tinggi lagi kedudukannya dalam organisasi tersebut.

2) Keterbukaan komunikasi dalam menciptakan iklim komunikasi yang kondusif berdasarkan aspek komunikasi bawahan dapat disimpulkan bahwa komunikasi dari bawahan kepada atasan sudah berjalan efektif yang artinya hubungan komunikasi bawahan dan atasan yang sesuai lingkungan yang ada dan seimbang. Adanya kesediaan atasan mendengarkan keluhan/ kesulitan dalam pekerjaan dan menerima saran/ gagasan yang disampaikan bawahannya dengan cara membuka pintu lebar-lebar bagi bawahan berkomunikasi mengenai pekerjaan kepada atasan.

3) Implikasi keterbukaan komunikasi dalam menciptakan iklim komunikasi yang kondusif di Kantor Perpustakaan dan Arsip Daerah (Kapusipda) Kabupaten Buleleng terlihat dengan adanya kepercayaan, kedekatan, dukungan, dan bersedia mendengarkan masalah, serta bersedia menerima kelebihan dan kekurangan.

\section{SARAN}

1) Masalah keterbukaan pada tingkat koordinator dan bawahan mengenai kemudahan memperoleh informasi dari atasan, cepat diselesaikan hal itu membuat bawahan kesulitan dalam mengetahui arah tujuan organisasi.

2) Kedekatan yang terjalin sebisa mungkin tercapai pada tingkat bawah dan tidak hanya sebatas pada tingkat koordinator.

3) Dalam pengambilan keputusan dan kebijakan organisasi keterlibatan bawahan harus dapat dijaga dan dipertahankan, begitu pula dengan pemberian kepercayaan antara atasan dengan bawahan dan rekan sekerja.

4) Memberikan pemahaman yang baik mengenai visi dan misi yang dapat mengarahkan staf berkinerja tinggi dalam pekerjaan.

\section{DAFTAR PUSTAKA}

DeVito, A. Joseph. 2011. Komunikasi Antarmanusia: Kuliah Dasar ed.5. Alih Bahasa Agus Maulana. Jakarta: Professional Books.

Hardjana, Andre. 2007. Iklim Komunikasi Organisasi : Jurnal Ilmu Komunikasi. Yogyakarta : Fisip Universitas Atma Jaya.

Masmuh, Abdullah. 2010. Komunikasi Organisasi: Dalam Perspektif Teori dan Praktek. Malang : UMM Press.

Morissan. 2009. Teori Komunikasi Organisasi. Bogor: Ghalia Indonesia.

Muhammad, Arni. 2011. Komunikasi Organisasi. Jakarta : Bumi Aksara.

Nasution. 2003. Metode Penelitian Naturalistik Kualitatif. Bandung:Tarsito.

Pace, R. Wayne and Don F. Faules. 2010. Komunikasi Organisasi: Strategi Meningkatkan Kinerja Perusahaan. Bandung: PT Remaja Rosdakarya.

Parwito. 2008. Penelitian Komunikasi Kualitatif. LKiS. Yogyakarta.

Rachmawati, Tine Silvana. 2009. Pengembangan Organisasi dan Anggota Ikatan Pustakawan Indonesia. Bandung: Unpad Press. Rakhmat, Jalaluddin. 2008. Psikologi Komunikasi. Bandung : Remaja Rosdakarya. 
Sugiarto, Agus dan Wahyono, Teguh. 2005. Manajemen Kearsipan Modern. Yogjakarta : Gava Media.

Sugiyono. 2012. Metode Penelitian Kuantitatif Kualitatif dan $R \& D$. Bandung: Alfabeta.

Sulistyo Basuki. 1996. Pengantar Kearsipan. Jakarta: Universitas Terbuka.
1993. Pengantar Ilmu Perpustakaan. Jakarta: Gramedia Pustaka Utama.

Sutarno NS. 2006. Manajemen Perpustakaan: Suatu Pendekatan Praktik. Jakarta: Sagung Seto.

Yin, Robert K. 2013. Studi Kasus: Desain dan Metode. Jakarta: Rajawali Pers. 